\title{
口研究論文
}

\section{寒冷地における児童の都市公園選択利用の 季節差に関する研究}

\author{
Analysis of Seasonal Differences of Children's Urban Park Usage in Snow Cold District
}

\author{
椎野亜紀夫* 愛甲 哲也 ${ }^{* *}$ \\ Akio SHIINO Tetsuya AIKOH
}

\begin{abstract}
This paper aimed at clarifying the current circumstances and seasonal differences of children's outdoor plays, and analyzing the factors that affect their behaviors in snow cold district. As a result of questionnaire survey, 1,390 children responded effective answers, and following points were made clear: 1. Frequency and travel time from their own home to children's outdoor playground both felled-off in winter period, 2. Open spaces located close to children's own home were more frequently used as their playground in winter, 3. Parents' opinions about their children's outdoor play in winter affected the frequency of children's outdoor plays, 4. Changing patterns of children's urban park uses between summer and winter were not changed in a single uniform way, but changed into three typical types, such as Type I: use decreased in winter period, Type II: continually used through a whole year, and Type III: use increased in winter period.
\end{abstract}

Keywords : children, outdoor activity, seasonal differences, urban park, snow cold district

キーワード : 子ども, 外遊び, 季節差, 都市公園, 積雪寒冷地

\section{1.はじめに}

積雪寒冷地では冬季の積雪により外遊び環境が一変し, 夏季と 比較して子どもの外遊び頻度が著しく低下することが指摘されて いる ${ }^{1)}$ 。札幌管区気象台によれば，札幌市の年間累計降雪量は平 年值で $587 \mathrm{~cm}, 2012$ 年度は $628 \mathrm{~cm}$ を記録し, 住宅地内は冬期間 の除雪が毎年必要となる。密集市街地においては雪の保管場所確 保が困難となることから, 都市公園等のオープンスペースに道路・ 私有地からの大量の雪が搬入されることになり，面積規模の小さ い都市公園の中には冬季の遊び場としての機能を果たさなくなる 事例屯多く見られ，冬季における外遊びを阻害する原因になって いると考えられる。しかしながら一方で，降雪による遊び環境の 劇的な変容は積雪寒冷地ならではの特徵であり, 雪を使った外遊 びという遊び環境の魅力を大いに高めるものととらえることもで

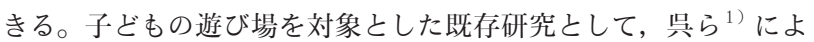
る公園再整備による利用の変化に関する研究, 近藤ら ${ }^{2)}$ による子 どもの屋外活動に関する研究, 市岡 ${ }^{3)}$ による児童期の遊び環境と 帰属意識に関する研究などが見られ, また子どもの屋外遊びに対 する保護者の影響に関する研究として雨宮 ${ }^{4)}$ による保護者による 許可から捉えた子どもの移動自由性と屋外遊びとの関連に関する 研究, 雨宮ら ${ }^{5)}$ による子どもに対する保護者の行動規制の要因と 遊びへの影響に関する研究などが見られる。一方で, 積雪寒冷地

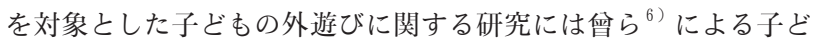
もの外遊びと遊び場に関する意識の変化に関する研究, 浅川ら ${ }^{7}$,

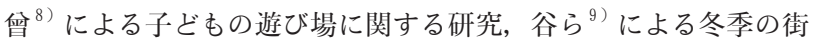

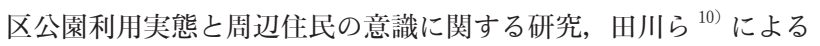
全天候型遊び場である地域施設の特徴に関する研究, 阿部ら ${ }^{11)} に$ よる子どもの遊び場選好に関する研究などが見られる。このうち 特に曾 $ら^{6)}$, 浅川 ${ }^{7}$, 曾 ${ }^{8)}$ の研究成果として, 夏季 /冬季とも に都市公園がもっとも遊び場として活用されていること, 夏季に 比べ冬季は外遊び頻度が減少するものの都市公園利用の移動距離 は季節間で変化が少ないことなどが指摘されているが，各季節の
公園利用の理由や，利用される公園単位での分析が十分になされ ては扔らず，夏季と状況が異なる積雪寒冷地の冬季の公園利用を 促す要因が十分に解明されていない。積雪寒冷地においては都市 公園に冬季の雪堆積場所としての機能が要求され, 児童の遊び場 との機能的両立にはさらなる研究蓄積を要する。一方で, これま で住区基幹公園の多くは標準面積, 誘致距離という考え方に基づ いて計画的整備が進められてきており, 利用の公平性を担保する 上で一定の役割を果たしてきた。しかしながら積雪寒冷地におい ては, 冬季の積雪にともなう路面凍結により利用先の都市公園ま でのアクセシビリティが著しく低下，夏季と比較して都市公園利 用の選択性の自由度低下を招く状況にある。このことは, 利用の 季節差を考慮した積雪寒冷地独自の利用計画の必要性を示唆する ものと考えられるが，このような積雪寒冷地の都市公園利用の特 殊性に着目した研究は十分な蓄積がなく, 季節差に配慮した都市 公園の利用計画の向上に援用する基礎研究が必要之されている。

以上を踏まえて本研究は, 積雪寒冷地における子どもの外遊び の実態（夏季／冬季の季節差を含む実態）を把握した上で，都市 公園利用の季節間変動（夏季 $\rightarrow$ 冬季でどのように変わるか）およ び変動のメカニズムの解明を目的に調査・研究を行った。また冬 季の外遊びと保護者の外遊びに対する意識との関係についても解 明を試み, 積雪寒冷地における子どもの外遊び実態とその規定条 件について整理し, 冬季における外遊びの促進・向上に向けた計 画づくりに援用することを研究意義として位置づけた。

\section{2. 調査方法}

札幌市内の小学校 10 校の協力を得て, 小学 2 年生および 5 年 生を対象としたアンケート調查を行った。アンケート調查は 2012 年 10 月〜2012 年 11 月に期間に実施した。調査対象小学校 へ調查票を持参・留置し, 各小学校に対して児童への配付・小学 校での回収を依頼, 約 1 週間後に再度小学校を訪問し, 調查票の 回収を行った。調査項目として外遊びの頻度, 遊びの内容, むっ

\footnotetext{
${ }^{*}$ 北海道科学大学工学部都市環境学科 ${ }^{* *}$ 北海道大学大学院農学研究院
} 
表 -1 調査票回収数・回収率

\begin{tabular}{|c|r|r|r|}
\hline 小学校名 & 児童数(名) & 回収票数(票) & 回収率 \\
\hline A小学校 & 170 & 130 & $76.5 \%$ \\
\hline B小学校 & 212 & 191 & $90.1 \%$ \\
\hline C小学校 & 220 & 180 & $81.8 \%$ \\
\hline D小学校 & 154 & 135 & $87.7 \%$ \\
\hline E小学校 & 291 & 250 & $85.9 \%$ \\
\hline F小学校 & 134 & 79 & $59.0 \%$ \\
\hline G小学校 & 132 & 109 & $82.6 \%$ \\
\hline H小学校 & 195 & 135 & $69.2 \%$ \\
\hline I小学校 & 48 & 43 & $89.6 \%$ \\
\hline J小学校 & 166 & 138 & $83.1 \%$ \\
\hline 合計 & 1722 & 1390 & $80.7 \%$ \\
\hline
\end{tabular}

ともよく遊びに行く場所とその理由, 遊び場までの移動時間等に ついて夏季/冬季に分けて記述回答を求めた。合わせて児童の保 護者に対しても冬季における子よ゙もの外遊びに対する意識, 遊び 場のあり方等について回答を求めた。調査の結果, 対象者 1722 名中 1390 名の児童（ならびにその保護者）から有効回答が得ら れた（回収率 $80.7 \% ，$ 表一 1 )。

\section{3. 研究結果}

（1）子どもの外遊びの実態（夏季／冬季比較）

(i ) 外遊びの頻度

アンケート調査結果をもとに, 各児童の外遊びの頻度について 夏季 /冬季に分けて回答をまとめたところ, 図一 1 に示したよう な結果となった。夏季では「ほぼ毎日」外に遊びに行くと回答し た児童が 1390 名中 526 名（37.8\%）「週 3〜4 日程度」が 441 名

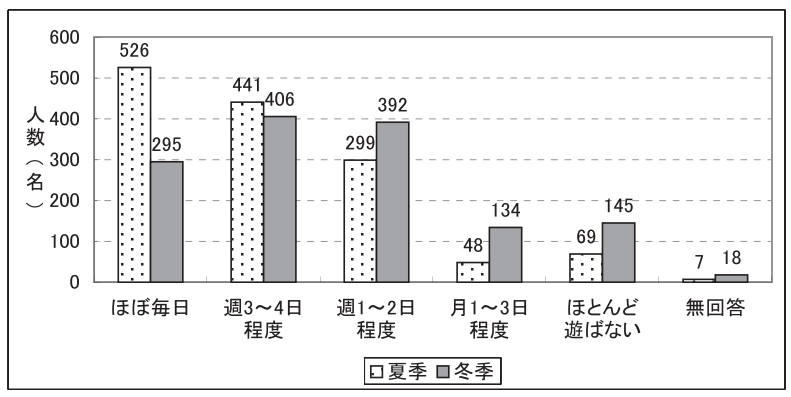

図-1 外遊び頻度の比較（夏季／冬季）

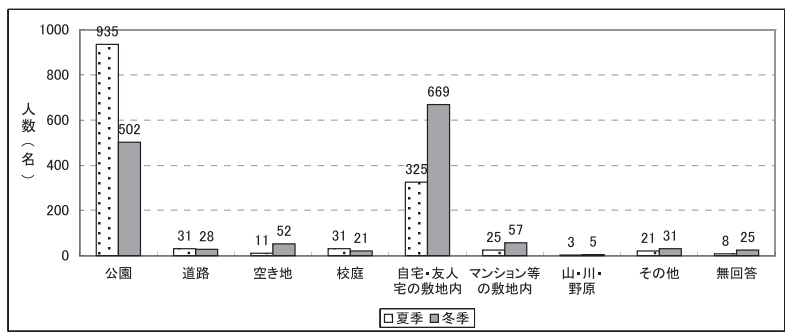

図一２ もっともよく遊ぶ場所（夏季／冬季）

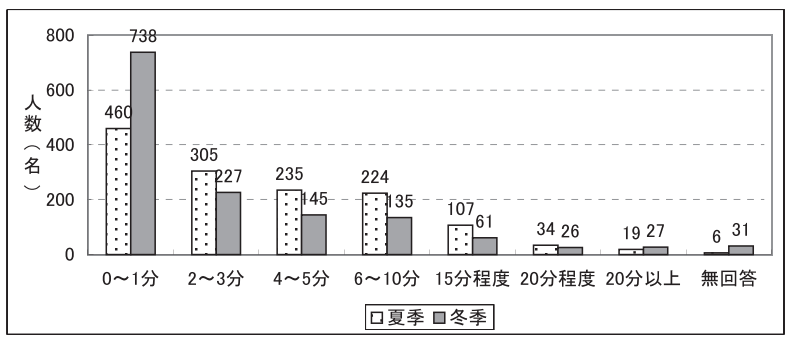

図ー3 遊び場までの移動時間（夏季／冬季）
(31.7\%)，「週 1〜2 日程度」が 299 名（21.5\%）であったのに対 して，冬季では「ほぼ毎日」が 1390 名中 295 名 (21.2\%),「週 $3 \sim 4$ 日程度」が 406 名 (29.2\%), 「週 1 2 日程度」が 392 名 (28.2\%)，また「ほとんど遊ばない」と回答した児童が 145 名 (10.4\%) という結果であった（ $<<0.001 ， \chi^{2}$ 検定による)。すなわ ち冬季では夏季に比べて外遊びの頻度が減少する傾向が見られた。

(ii）もっと屯よく遊ぶ場所

外遊びでもっともよく遊ぶ場所についてまとめた結果, 夏季／ 冬季いずれも「公園」「自宅・友人宅の敷地内」が多く見られた (図-2)。季節別では「公園」は夏季 935 件, 冬季 502 件と夏季 の件数が多いのに対し,「自宅・友人宅の敷地内」は夏季 325 件, 冬季 669 件と冬季の方が件数が多い結果となった（p<0.001， $\chi^{2}$ 検定による)。また件数としてはあまり多くないものの「空き地」 は夏季 11 件, 冬季 52 件と冬季の件数が多い結果となった。冬季 は積雪により移動手段として自転車の利用が困難になり，自宅周 辺を遊び場として活用する機会が多くなるのではないかと推察さ れた。

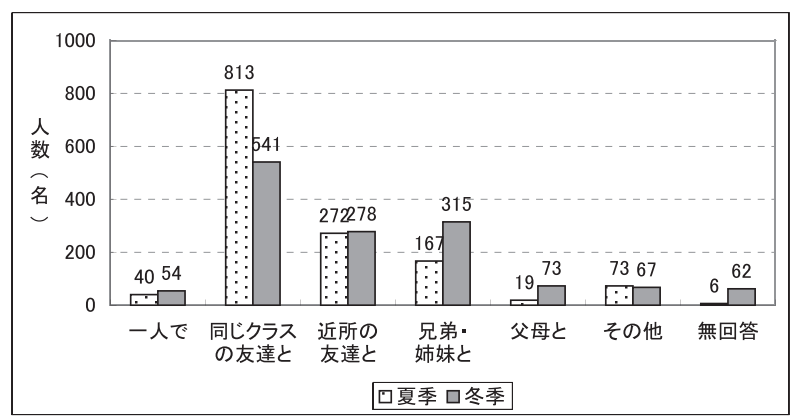

図 -4 遊び相手 (夏季/冬季)

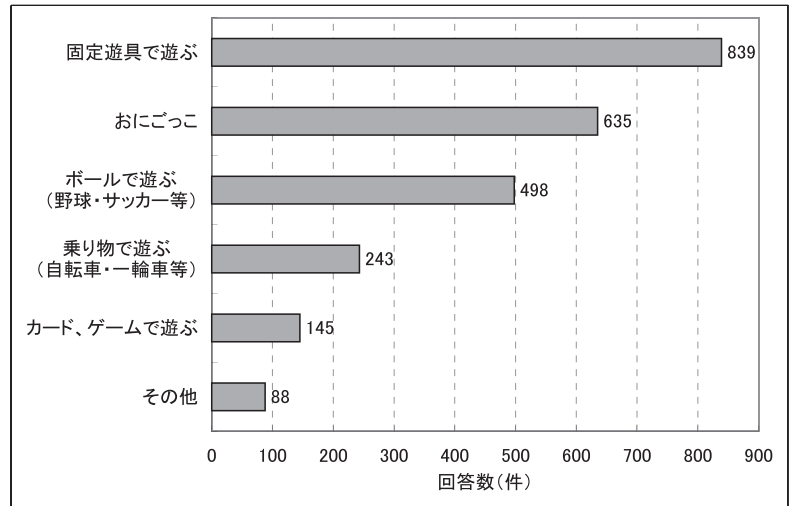

図 5 遊びの内容（夏季, 複数回答)

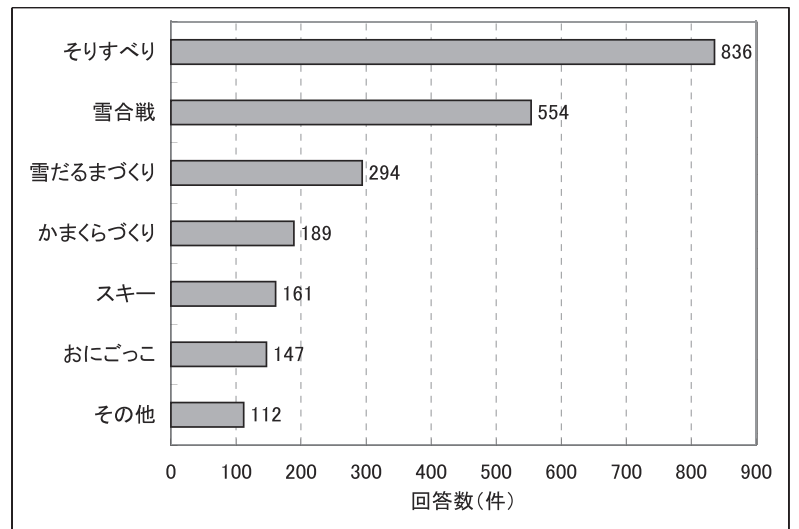

図-6 遊びの内容（冬季, 複数回答） 
（iii）遊び場までの移動時間

遊び場までの移動時間は，夏季では「 $「 0 \sim 1$ 分」が 460 件 (33.1\%), 「2 3 分」が 305 件 (21.9\%), 「4 5 分」が 235 件 (16.9\%)，「6〜10 分」が 224 件（16.1\%）と比較的分散する 結果であったのに対して，冬季では「0〜1 分以内」が 738 件 (53.1\%) と夏季に比べて集中する傾向が見られた（ $<<0.001 ， \chi^{2}$ 検定による, 図-3)。先の「もっともよく遊ぶ場所」の結果と 合わせると, 冬季は降雪と寒さにより遊び場までの移動時間が短 く, 自宅の敷地内等の私有地が遊び場として活用される傾向にあ ることが明らかとなった。

\section{(iv) 遊び相手}

遊び相手では「同じクラスの友達と」が夏季では 813 件 (58.5\%) であったのに対し冬季では 541 件 (38.9\%) と冬季の方が少なく， 「兄弟・姉妹と」が夏季では 167 件 (12.0\%), 冬季では 315 件 (22.7\%) と冬季の方が多い結果となった（ $\mathrm{p}<0.001 ， \chi^{2}$ 検定に よる, 図-4)。冬季はもっともよく遊ぶ場所として自宅等の敷

表 -2 利用する公園の選択理由（夏季）

\begin{tabular}{|c|c|c|}
\hline 理由 & $\begin{array}{l}\text { 指摘 } \\
\text { 件数 }\end{array}$ & 記述内容 \\
\hline 仲間がいる & 164 & $\begin{array}{l}\text { 「同じクラスの子がそこに行くから」「友達とよく遊ぶ公園だ } \\
\text { から」、「友達がいっぱい集まるから」、「つもみんなが集ま } \\
\text { る場所だから」 }\end{array}$ \\
\hline 自宅から近い & 150 & $\begin{array}{l}\text { 「近くて遊びやすい」、近くて便利だから」、「家の前にある公 } \\
\text { 園だから」 }\end{array}$ \\
\hline 面積が広い & 107 & $\begin{array}{l}\text { 「遊ぶ場所が広いから」、「大きくていっぱい走れるから」、「近 } \\
\text { くの公園の中でー番大きいから」、「ひろくておおぜいで遊べ } \\
\text { るから」 }\end{array}$ \\
\hline $\begin{array}{l}\text { 固定遊具が面白 } \\
\text { い/たくさんある }\end{array}$ & 100 & $\begin{array}{l}\text { 「遊具が多くて楽しいから」「他の公園にはない遊具がある } \\
\text { から」、「家の近くにはないけど好きな遊具があるから」 }\end{array}$ \\
\hline $\begin{array}{l}\text { 特定の遊びがで } \\
\text { きる }\end{array}$ & 73 & $\begin{array}{l}\text { 「野球をするグラウンドがあるから」、水遊びができるから」、 } \\
\text { 「自転車に乗れる場所があるから、「优てルができるか } \\
\text { ら」 }\end{array}$ \\
\hline
\end{tabular}

表－３利用する公園の選択理由（冬季）

\begin{tabular}{|c|c|c|}
\hline 理由 & $\begin{array}{l}\text { 指摘 } \\
\text { 件数 }\end{array}$ & 記述内容 \\
\hline 仲間がいる & 164 & $\begin{array}{l}\text { 同じクラスの子がそこに行くから」「友達とよく遊ぶ公園だ } \\
\text { から」、「友達がいっぱい集まるから」、「いつもみんなが集ま } \\
\text { る場所だから」 }\end{array}$ \\
\hline 自宅から近い & 150 & $\begin{array}{l}\text { 「近くて遊びやすい」、近くて便利だから」、「家の前にある公 } \\
\text { 園だから」 }\end{array}$ \\
\hline 面積が広い & 107 & $\begin{array}{l}\text { 「遊ぶ場所が広いから」、「ききてていっぱい走れるから」「近 } \\
\text { くの公園の中で一番大きいから」、ひろくておおぜいで遊べ } \\
\text { るから」 }\end{array}$ \\
\hline $\begin{array}{l}\text { 固定遊具が面白 } \\
\text { いたたくさんる }\end{array}$ & 100 & $\begin{array}{l}\text { 「遊具が多くて楽しいから」「他の公園にはない遊具がある } \\
\text { から」、「家の近くにはないけど好きな遊具があるから」 }\end{array}$ \\
\hline $\begin{array}{l}\text { 特定の遊びがで } \\
\text { きる }\end{array}$ & 73 & $\begin{array}{l}\text { [野球をするグラウンドがあるから」、「水遊びができるから」、 } \\
\text { 「自転車に乗れる場所があるから」、ボー斿びができるか } \\
\text { ら」 }\end{array}$ \\
\hline
\end{tabular}

\section{表 -4 冬季の外遊びに対する保護者の意識}

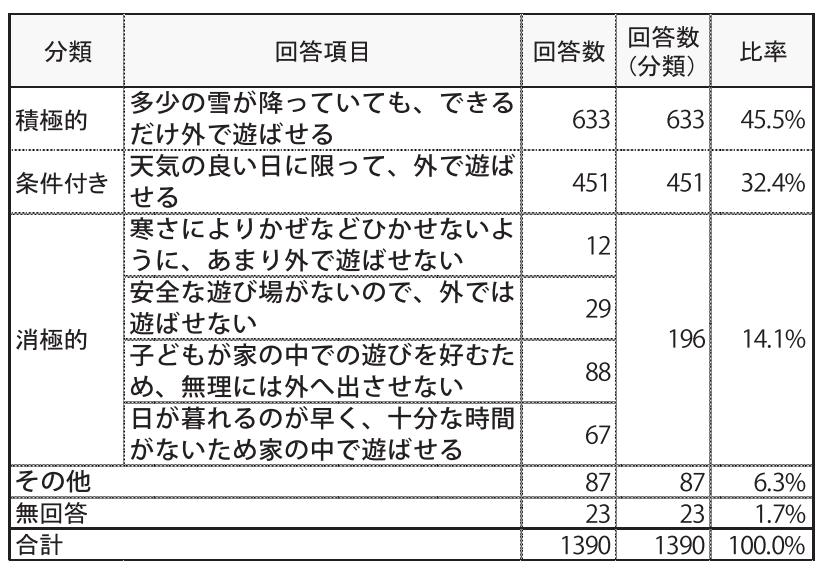

地内が多くなることから，同居する兄弟と一緒に遊ぶ傾向が高く なるのではないかと推察された。

( v ) 遊びの内容

遊びの内容について夏季／冬季に分けて集計した結果，夏季は 「固定遊具で遊ぶ」(839 件),「おにごっこ」(635 件),「ボールで 遊ぶ」(498 件) が多く見られた（図一-5) のに対して，冬季で は「そりすべり」(836 件),「雪合戦」(554 件)，「雪だるまづくり」 （294 件）など, 積雪寒冷地である対象地の地域特性を反映し, 季節による遊び内容の明確な差異が見られた（図－6）。

（vi）利用する公園の選択理由

日常的にもっとも利用する公園の名称を夏季／冬季に分けて尋 ね，その公園を利用する理由について尋ねた結果をまとめたもの が表 -2 , 表 -3 である。指摘件数が多かった回答のうち, 夏季 〈冬季ともに共通する理由として「仲間がいる」,「自宅から近い」, 「面積が広い」の 3 項目があげられる。夏季における理由では「仲 間がいる」が指摘件数 164 件ともっとも多く見られたのに対し， 冬季に打いては「雪遊びができる/雪山がある/雪が多い」が 190 件ともっとも多く見られた。季節別の理由の差異としては,

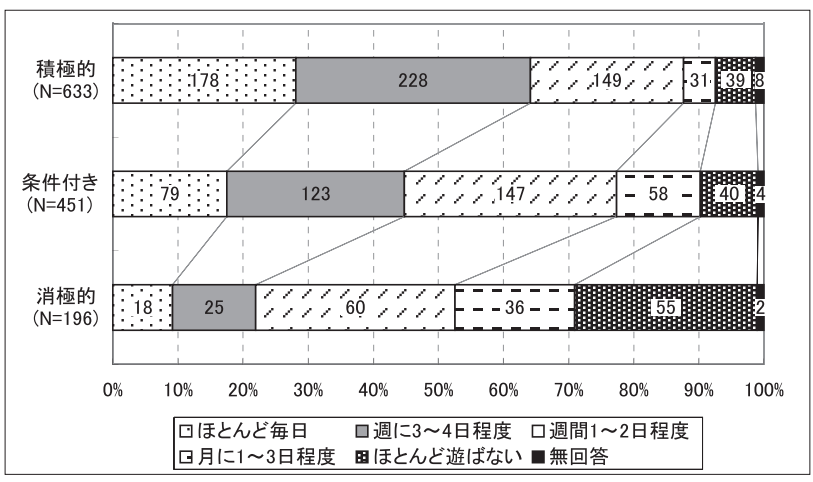

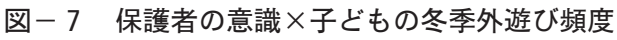

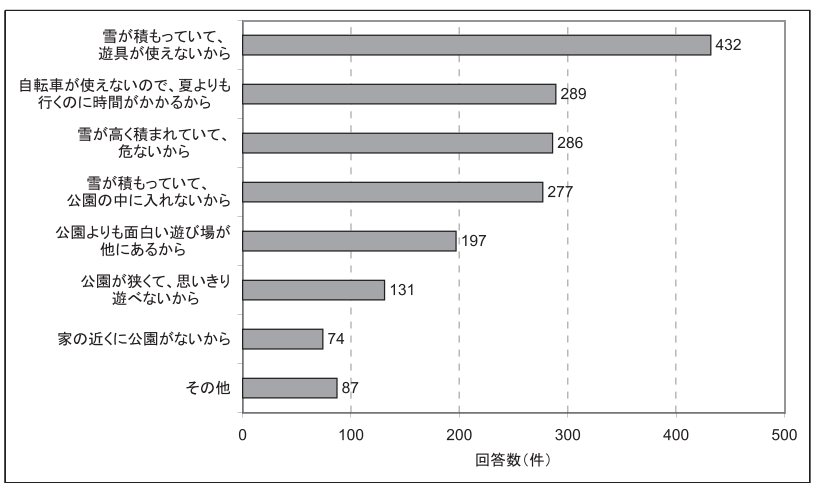

図-8 冬季に公園を利用しない理由（複数回答）

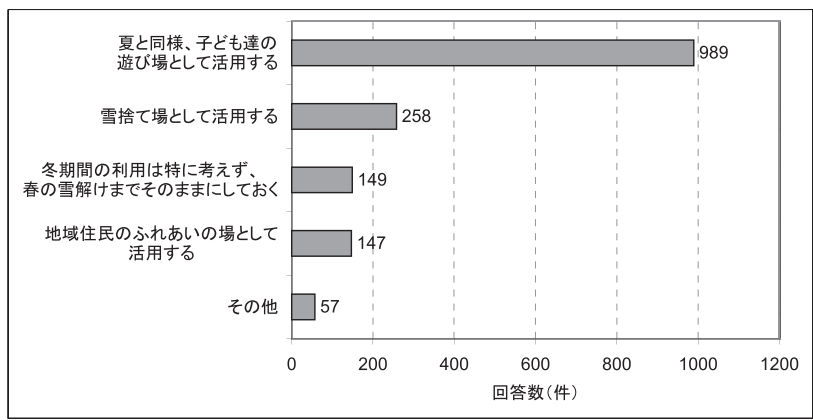

図－9 冬季の公園のあり方（保護者意見，複数回答） 
夏季が「固定遊具が面白い/たくさんある」,「特定の遊びができ る」など, 公園内部の遊戯施設や運動施設に関する記述が多く見 られた一方で, 冬季では積雪により固定遊具等の施設がほとんど 利用できなくなるためか, 遊戯施設や運動施設に関する理由はほ とんど見られず，代わりに「雪遊びができる／雪山がある／雪が 多い」といった公園内の積雪を利用した遊びができることが理由 として多くあげられていた。

\section{（2）冬季の外遊びと保護者の意識との関係}

次に, 冬季の外遊びに対する保護者意識が, 児童の外遊びに影 響を与えているのではないかと考え, これらの関係について分析 を行った。冬季の外遊びに対する保護者の意識についてアンケー 卜調查を行った結果が表一 4 である。回答項目のうち,「多少の 雪が降っていても，できるだけ外で遊ばせる」を「積極的」，「天 気の良い日に限って, 外で遊ばせる」を「条件付き」,「寒さによ りかぜなどひかせないように，あまり外で遊ばせない」，「安全な 遊び場がないので, 外では遊ばせない」,「子どもが家の中での遊 びを好むため, 無理には外へ出させない」,「日が暮れるのが早く, 十分な時間がないため家の中で遊ばせる」を「消極的」として集 計した結果, 外遊びに対する意識として「積極的」が 1390 名中 633 名 (45.5\%), 「条件付き」が 451 名 (32.4\%),「消極的」が 196 名（14.1\%）となり，4 割以上の保護者が冬季の外遊びに対 して積極的な考えを持っていることが明らかとなった。さらに保 護者の意識と子どあの冬季外遊び頻度との関係について分析した 結果, 外遊びに対する保護者の意識が「積極的」なグループの方 が「ほとんど毎日」外で遊ぶ子どもの割合が 633 名中 178 名 (28.1\%) と高く,一方で「消極的」なグループでは「ほとんど
遊ばない」と回答した割合が 196 名中 55 名（28.1\%）となった $\left(\mathrm{p}<0.001: \chi^{2}\right.$ 検定による, 図 -7$)$ 。このことから冬季の外遊び に対する保護者の意識が, 子どもの外遊び頻度に強く影響を与え ていることが示唆された。

\section{（３）冬季の公園利用, 公園のあり方}

冬季に公園を利用しないと回答した児童に対しその理由を複数 回答で尋㸚た結果，「雪が積もっていて，遊具が使えないから」 が 432 件, 「自転車が使えないので, 夏よりも行くのに時間がか かるから」が 289 件, 「雪が高く積まれていて, 危ないから」が 286 件, 「雪が積もっていて, 公園の中に入れないから」が 277 件指摘された（図－8）。積雪寒冷地である札幌市では，車での 移動利便性確保のため車道の除雪・排雪はされるものの, 都市公 園内が除雪・排雪されることはほとんどなく, むしろ周辺の住宅 敷地等から公園敷地内へ雪が搬入され，冬季における遊び場確保 の妨げになっていると考えられる。

一方，保護者に対して冬季の公園のあり方について尋ねた結果 (複数回答),「夏と同様, 子どもたちの遊び場として活用する」 が 989 件と最多を占め, 多くの保護者が子どもの遊び場として利 用すべきと回答していた一方，「雪捨て場として活用する」が 258 件を占め，児童がいる世帯ですら雪捨て場としての活用が望

表 $-6 \quad$ 利用の季節間変動

\begin{tabular}{|c|c|c|}
\hline 夏季利用 & 冬季利用 & 季節間変動 \\
\hline 有り & 無し & 「流出」 \\
\hline 有り & 有り & 「継続」 \\
\hline 無し & 有り & 「流入」 \\
\hline
\end{tabular}

表 -5 公園別の夏季 $\rightarrow$ 冬季利用変動一覧

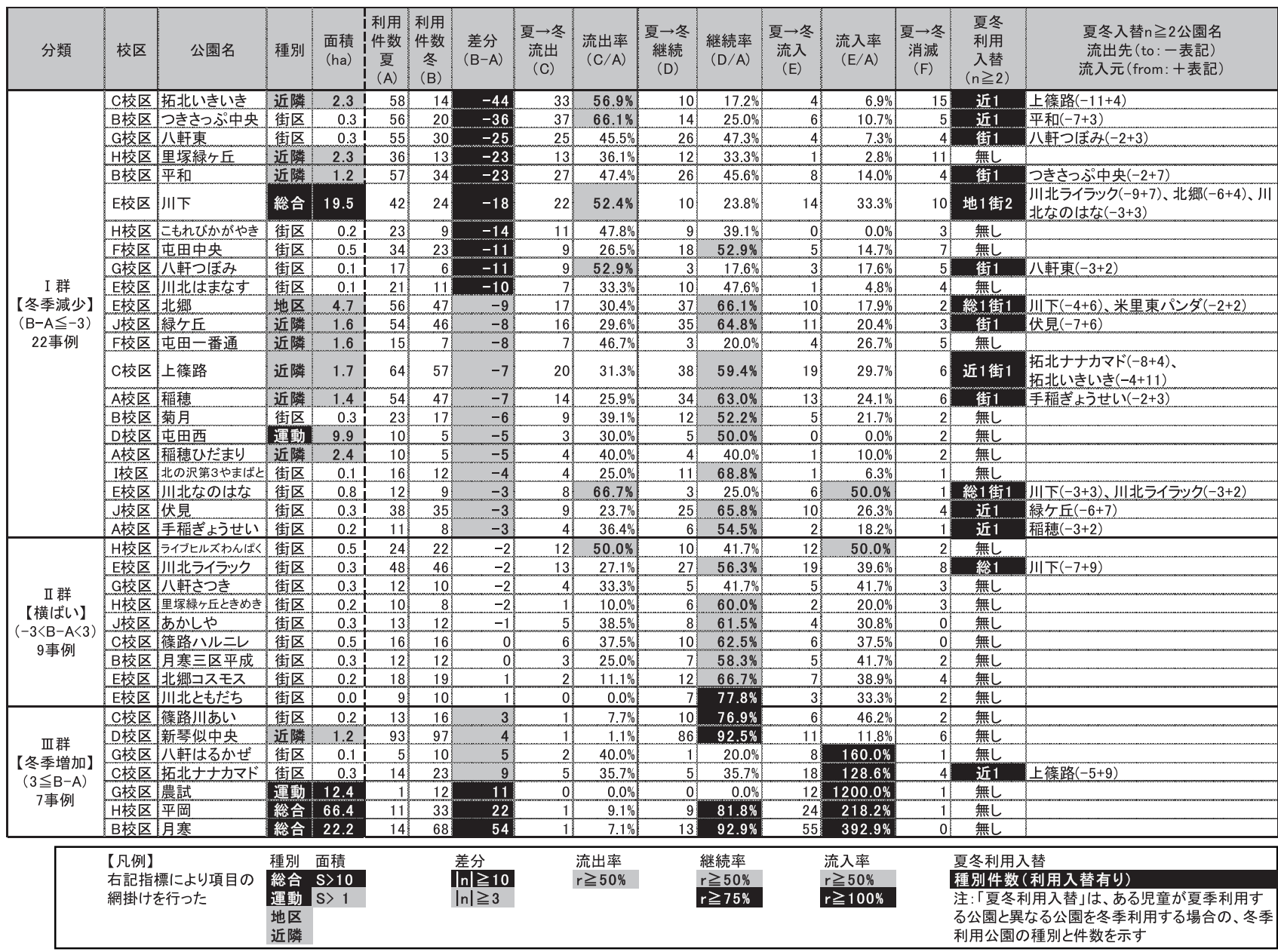




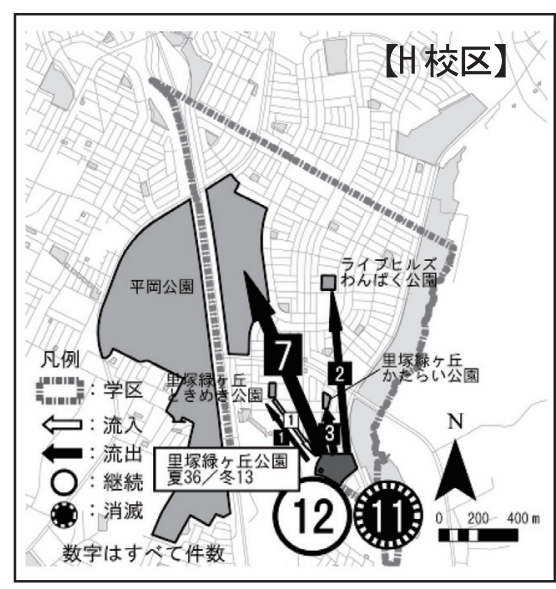

図-10 | 群【冬季減少】事例

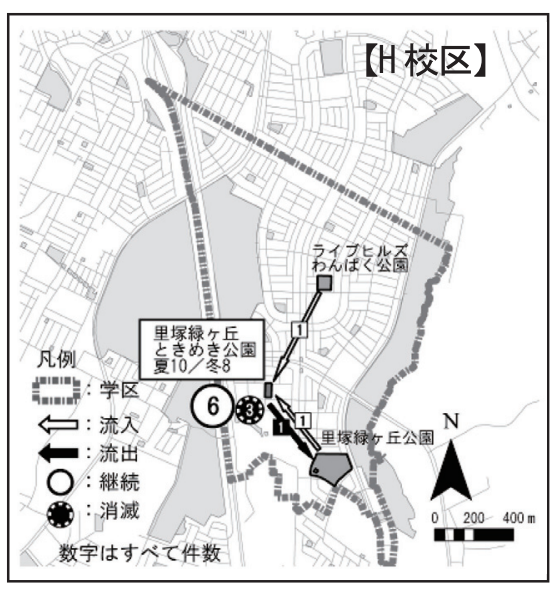

図-11 II群【横ばい】事例

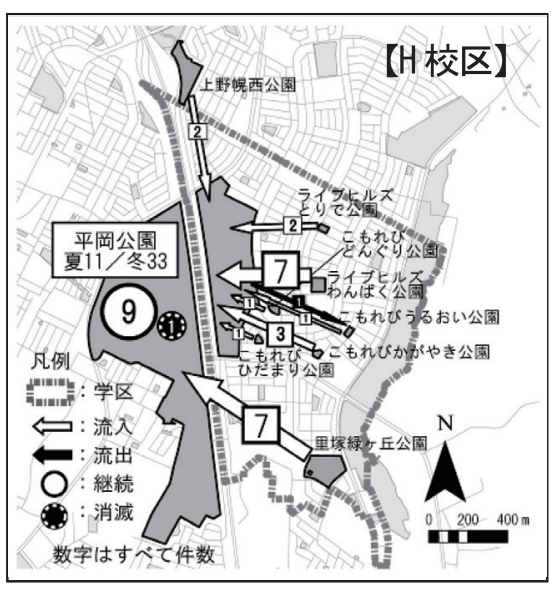

図-12 III群【冬季増加】事例

\begin{tabular}{|c|c|c|c|c|c|c|}
\hline \multirow{2}{*}{ 理由 } & \multicolumn{2}{|c|}{ I 群流出 } & \multicolumn{2}{|c|}{ II 群継続 } & \multicolumn{2}{|c|}{ III群流入 } \\
\hline & 件数 & 比率 & 件数 & 比率 & 件数 & 比率 \\
\hline 自宅から近い & 130 & $43.2 \%$ & 56 & $65.1 \%$ & 27 & $20.5 \%$ \\
\hline $\begin{array}{l}\text { 雪遊びができる/雪山 } \\
\text { がある/雪が多い }\end{array}$ & 100 & $33.2 \%$ & 17 & $19.8 \%$ & 74 & $56.1 \%$ \\
\hline 面積が広い & 26 & $8.6 \%$ & 4 & $4.7 \%$ & 23 & $17.4 \%$ \\
\hline 仲間がいる & 11 & $3.7 \%$ & 2 & $2.3 \%$ & 3 & $2.3 \%$ \\
\hline その他 & 34 & $11.3 \%$ & 7 & $8.1 \%$ & 5 & $3.8 \%$ \\
\hline 合計 & 301 & $100.0 \%$ & 86 & $100.0 \%$ & 132 & $100.0 \%$ \\
\hline
\end{tabular}

ましいと考える保護者も多くいることが明らかとなった（図－9）。 （4）都市公園利用の季節間変動

次に, 外遊び場の中でも都市公園に注目し, 児童一人一人が夏 季/冬季で都市公園をどのように選択利用しているのかについて 分析を行った。アンケート調査項目として,「夏季にもっとも利 用する公園名」,「冬季にもっとも利用する公園名」を記述しても らい, 各自の利用頻度がもっとも高い都市公園が季節によってど う変動するのか, 夏季 /冬季別の公園利用の比較と, 冬季におけ る利用者の公園選択の理由から解明を試みた。まずアンケート結 果で公園名があげられた都市公園の中から，夏季または冬季に一 定以上の利用が見られる都市公園（便宜上，夏季／冬季のいずれ かで利用件数 10 件以上の都市公園とした）を対象とした結果, 38 力所が抽出された。次に夏季の利用件数と冬季の利用件数の 差によって並び替えを行い, 便宜上 \pm 3 件を閾値としてデー夕を 分類し, I 群【冬季減少】, II 群【横ばい】, III群【冬季増加】の 3 つに分けた。それぞれのサンプル数は I 群が 22 , II 群が 9 , III群が 7 であった（表－5）。

各サンプルの都市公園利用における季節間変動の指標として, 一人の児童が夏季ならびに冬季にもっとも利用すると回答した公 園を比較し, ある特定の公園について夏季利用「有り」かつ冬季 利用「無し」を「流出」, 夏季利用「有り」かつ冬季利用「有り」 を「継続」, 夏季利用「無し」かつ冬季利用「有り」を「流入」 と定義し (表一 6 )，それぞれの該当件数を表 -5 中に記載した。 併せて夏季の利用件数を分母とした比率をそれぞれ「流出率」,「継 続率」「流入率」として算出し, 公園名が夏季のみ記述され冬季 は空欄もしくは「利用しない」旨の記述がされたものについては 「消滅」とした。また, 特定の 2 都市公園間で夏季/冬季の利用 が入れ替わっている（以下，「利用入替」と定義する）ケースが 複数見られたことから，2 件以上の利用入替が見られた当該公園

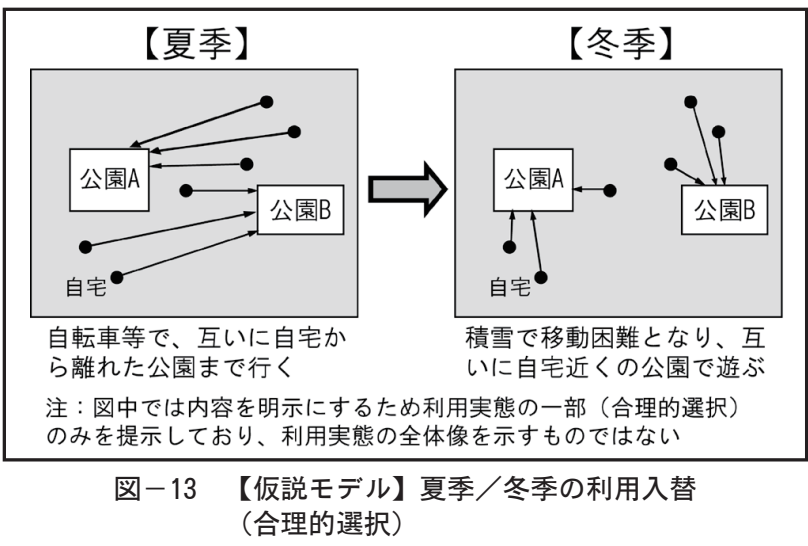

の種別と簓所数, 公園名, ならびに流出件数, 流入件数を記載し た。なお表中の項目別特徵を明示するため, 各項目の值の散らば りを考慮し「種別」は近隣公園以上を，「面積」は 1ha と 10ha より大きい值を，「差分」は絶対值 3 以上と 10 以上を，「流出率」 は $50 \%$ 以上を，「継続率」は $50 \%$ 以上と $75 \%$ 以上を，「流入率」 は $50 \%$ 以上と $100 \%$ 以上を，「夏冬利用入替 $(n \geqq 2) 」$ は該当公 園の種別と件数を強調表示した。以下, I 群〜 III 群の特徵につい て述べる。

\section{(i ) I 群【冬季減少】の特徵}

I 群【冬季減少】に該当する都市公園は 22 事例見られた。積 雪寒冷地に扔いては通常, 夏季と比較して冬季の利用件数が減少 することは既存研究 ${ }^{6)}$ においても指摘されており, また図 -1 で提示した外遊びの利用頻度の夏季/冬季比較においても確認さ れた。夏季と冬季の減少幅が大きかった事例として拓北いきいき 公園（夏季 58 件／冬季 14 件, 44 件減少), つきさっぷ中央公園 （夏季 56 件／冬季 20 件, 36 件減少）八軒東公園（夏季 55 件／ 冬季 30 件, 25 件減少), 里塚緑ヶ丘公園（夏季 36 件／冬季 13 件, 23 件減少), 平和公園 (夏季 57 件 /冬季 34 件, 23 件減少) などが見られた。種別・面積では, 近隣公園以上で面積 1 ha 以 上の事例が 22 件中 11 件見られた。夏季/冬季の利用を比較した 流出率，継続率，流入率では, 継続率 $50 \%$ 以上の事例が 22 件中 10 件見られたこと以外は特に目立った特徵は見られなかったも のの, 夏季/冬季で利用入替が 2 件以上見られたケースは 22 事 例中 13 事例と II 群, III群と比べて多く見られた。

\section{（ii）【群【横ばい】の特徵}

II群【横ばい】に該当する都市公園は 9 事例見られた。I 群, III群では種別が近隣公園以上, 面積 1 ha 以上の公園が複数見ら れたが，II群に含まれる公園事例はすべて街区公園で面積 0.5ha 
以下であった。流入率，流出率は 1 事例を除いて $50 \%$ 未満にと どまった一方，継続率では 9 事例中 7 事例で $50 \%$ を超えており, 年間を通じて同一の児童による継続的利用が見られた。夏季/冬 季 2 件以上の利用入替は 9 事例中 1 事例しか見られなかった。

\section{(iii） III群【冬季増加】の特徵}

III群【冬季増加】に該当する都市公園は 7 事例見られた。公園 種別・面積では面積規模の小さい街区公園または近隣公園が 4 事 例見られた一方, 面積規模の大きい総合公園または運動公園が 3 事例見られた。夏季と比較して利用増加が特に顕著であった事例 として月寒公園 (夏季 14 件 /冬季 68 件, 54 件増加), 平岡公園 （夏季 11 件 /冬季 33 件, 22 件増加), 農試公園（夏季 1 件 /冬 季 12 件, 11 件増加）が見られ, いずれも面積規模の大きい総合 公園または運動公園であった。夏季/冬季を比較した流入率では 特に目立った特徵は見られなかったが, 継続率では 7 事例中 4 事 例が継続率 $75 \%$ と高い割合を占めた。また流入率では 7 事例中 5 事例が夏季利用と比較して $100 \%$ を超える高い割合を占めた。ま た夏季／冬季の利用入替は 7 事例中 1 事例のみ見られた。またIII 群に含まれる公園事例うち農試公園に関しては, 公園敷地内に冬 季でも利用可能な屋内運動施設を有しており, これが冬季の利用 増加を促していることがアンケート結果から確認されている ${ }^{12)}$ 。

（iv）公園利用の季節間変動まとめ

夏季 /冬季別に見た都市公園利用の季節変動は, 上述のように I 群【冬季減少】, II 群【横ばい】, 而群【冬季増加】の 3 タイプ が見られたが，これらの具体的な形態について 1 校区を事例に考 察するとともに, 冬季利用の理由についてタイプ別の比較を行っ た。 $\mathrm{H}$ 校区 ${ }^{13)}$ を事例として I 群【冬季減少】, II 群【横ばい】, III群【冬季増加】に含まれる公園事例の利用の季節間変動を空間 的に整理した（図-10, 図-11, 図-12)。図-10で I 群【冬季 減少】の事例とした里塚緑ヶ丘公園（夏季 36 件／冬季 13 件）で は, 継続 12 件, 消滅 11 件, 流出 13 件, 流入 1 件の季節間変動 があり, 流出先の内訳として総合公園である平岡公園へ 7 件, 街 区公園である里塚緑ヶ丘かたらい公園, ライブヒルズわんぱく公 園へそれぞれ 3 件， 2 件の移動が見られた。また街区公園の里塚 緑ヶ丘ときめき公園では流出, 流入各 1 件の利用入替が見られた。 一方, 図-11 のII群【横ばい】事例は里塚緑ヶ丘ときめき公園（夏 季 10 件 /冬季 8 件）を中心に季節間変動を見ると, 前出の里塚 緑ヶ丘公園之 1 件の利用入替が見られたほか, ライブヒルズわん ぱく公園から 1 件の流入が見られた。また継続 6 件, 消滅 3 件で あり，利用の季節間変動は小さいことが視覚的にも確認された。 また図-12の III群【冬季増加】事例である平岡公園（夏季 11 件 ／冬季 33 件）を中心に季節間変動を見ると, 継続 9 件, 消滅 1 件であり, 街区公園であるこもれびうるおい公園へ 1 件の流出が 見られたほか, 周辺の複数の公園から合計 24 件の流入が見られた。 流入元として近隣公園である里塚緑ヶ丘公園, 街区公園であるラ イブヒルズわんぱく公園からそれぞれ 7 件と比較的多く流入が見 られ，冬季における外遊び場として頻繁に利用されていた。

一方で冬季利用の理由の中でも，I 群【冬季減少】は「流出」, II群【横ばい】は「継続」, III群【冬季増加】は「流入」の季節 間変動に限って理由をまとめた結果が表一7である（なお I 群に ついては, 流出元ではなく流出先の都市公園を利用する理由をま とめた)。冬季利用の理由としては「自宅から近い」,「雪遊びが できる/雪山がある/雪が多い」,「面積が広い」,「仲間がいる」 が多く見られたが, タイプ別に比較すると I 群【冬季減少】の流 出理由, ならびにII群【横ばい】の継続理由では「自宅から近い」 がそれぞれ 310 件中 130 件 (43.2\%)，86 件中 56 件 (65.1\%) と 最も高い割合を占めた。これに対して正群【利用増加】の流入理 由としては「雪遊びができる/雪山がある/雪が多い」が 132 件 中 74 件 $(56.1 \%)$ と最多を占めた ${ }^{14)}\left(\mathrm{p}<0.001 ， \chi^{2}\right.$ 検定による)。
すなわち I 群【冬季減少】の流出と【I群【横ばい】の継続に含ま れるケースの多くが，「自宅から近い」という自宅からのアクセ シビリティの高さを優先した，いわば「合理的選択」によって冬 季の公園利用先を決定していたのに対し， III群【冬季増加】の流 入では「雪遊びができる/雪山がある/雪が多い」といった冬季 の雪遊びができること，いわば「意欲的選択」によって冬季の公 園利用先を決定しているという異なる選択方法を採っていた。さ らにこのうち，「合理的選択」について季節間変動のモデル化を 試みた。I 群【冬季減少】で頻繁に見られた夏季／冬季の利用入 替として図一13のようなモデルを示す ${ }^{15)}$ 。すなわち，夏季に自 転車を利用して自宅から距離的に離れた公園を利用していた児童 が，冬季になると寒さと積雪による移動の困難さを理由として自 宅近くの公園を日常的に利用するようになり，これが公園利用の 相互入替を生起させているのではないかと推察された。

\section{4. おわりに}

本研究は積雪寒冷地を対象とし, 児童の都市公園利用が夏季／ 冬季によりどのように変動するのか, そのメカニズム解明を試み た。そのための基礎条件として子どもの外遊び実態について把握 した結果, 冬季の外遊びは夏季と比較して頻度が低下し, 遊び相 手は夏季は同じクラスの友達と遊ぶ機会が多いが冬季は兄弟・姉 妹と遊ぶ機会が多くなっていた。また特定の公園を利用する理由 として, 夏季は仲間がいることのほか公園内部の施設条件が理由 にあげられていた一方, 冬季では雪遊びができることがもっとも 多い理由としてあげられた。その反面, 冬季に都市公園を利用し ない理由として「雪が高く積まれていて危ない」,「雪が積もって いて公園の中に入れない」など, 地域の雪堆積場所となっている ことが児童の公園利用を阻害している実態が明らかとなった。加 えて,「自転車が使えないので，夏よりも行くのに時間がかかる」 といった, 冬季の積雪による利用先の公園までのアクセシビリティ 低下が公園利用を阻害している実態も見られ, 誘致距離を基準と した住区基幹公園の配置計画が冬季において必ずしも有効に機能 していない点が明らかとなった。

一方, 冬季の外遊びと保護者の外の遊びに対する意識との関係 について分析を行った結果, 保護者の意識が子どもの外遊び頻度 に強い影響を与えることが示唆された。このような外遊びの実態 については曾ら ${ }^{6)}$, 浅川ら ${ }^{7)}$, 曾 ${ }^{8)}$ により指摘されるところであ るが, 本研究においても類似の成果が得られたことから, 既存研 究成果に再現性があることが確認できた。その上に立ち, 本研究 における新知見として都市公園事例の詳細な分析を通じて夏季／ 冬季の利用を比較し, 公園利用の季節間変動は一律ではなく, 下 記の 3 パターンの変化があることを解明し, 既存研究成果を深化 させることができた。

すなわち, 都市公園利用の季節間変動（夏季／冬季の比較）を I 群【冬季減少】, II 群【横ばい】, 而群【冬季増加】に分けて分 析を行った結果, I 群【冬季減少】では夏季/冬季で遊ぶ公園の 利用入替が頻繁に起こっていること，II群【横ばい】では此較的 面積規模の小さい公園が夏季／冬季で継続的に利用されていたこ と, III群【冬季増加】では面積規模の大きい公園が見られ，他の 公園からの利用の流入が多く見られることが明らかとなった。冬 季に扔ける公園利用の理由について, I 群【冬季減少】は「流出」, II群【横ばい】は「継続」， III群【冬季増加】は「流入」の季節 間変動に限ってまとめた結果，I群【冬季減少】の流出とII群【横 ばい】の継続に含まれるケースの多くが，自宅からのアクセシビ リティの高さを優先する「合理的選択」により公園利用先を決定 していたのに対し, III群【冬季増加】の流入に含まれるケースの 多くでは，冬季に雪遊びができるという「意欲的選択」により公 園利用先を決定しているという 2 つの異なる選択がなされていた。 
さらに仮説としてではあるが，「合理的選択」が夏季／冬季間に おける公園利用の入替を誘発しているのではないかと推察された。 一方で積雪寒冷地では, 図- 7 の保護者意見でも確認された通 り都市公園に冬季における市街地内の雪堆積場所としての機能も 期待される。このことから冬季における都市公園利用促進に向け ては, 児童の冬季利用実態を考慮しつつ, 「遊び場利用を重視す る公園」と「雪堆積場利用を重視する公園」とに分けて利用計画 を策定する方法を提案する。このような冬季の公園利用計画づく りを検討するにあたり, 本研究の成果は一つの有用な知見を示す ものである。

以上の研究成果から冬季の外遊び促進のためには, こどもだけ でなく保護者に対して外遊びの魅力を伝える啓発活動が必要であ り, また冬季における外遊びの活動圈域縮小に対応した公園利用 計画, 特に雪捨て場との機能的な共存を含む計画づくりが必要で ある。さらに冬季の外遊び場所の選択利用には, 自宅からのアク セシビリティの高さを優先する「合理的選択」と, 冬季の雪遊び ができることを理由とする「意欲的選択」の 2 つがあることが明 らかとなった。このことから冬季における子どもの外遊び促進に 向けた方策として, 前者の合理的選択に対しては町内会等の近隣 組織との調整を行い, 地域の中で雪捨て場にする公園／雪捨て場 にしない公園に分けて排雪のコントロールを行う等の対応が有効 と考えられた。一方で後者の意欲的選択に対しては, 目的地とな る遊び場までの移動の安全性確保が必要であることに加え, イベ ント実施などにより冬季の都市公園利用の充実を図ることが望ま しいと考えられた。

\section{補注及び引用文献}

1 ）吳垠錫・木下剛・池邊このみ・廉戟振（2012）：小規模公園 の再整備による空間と利用の変化に関する研究 : ランドスケー プ研究 75(5), 471-476

2 ) 近藤樹理・山田あすか・松本真澄・上野淳 (2008) : 多摩 ニュータウンにおけるこどもの屋外活動に関する研究：日本 建築学会計画系論文集 73(628), 1251-1258

3 ）市岡綾子（2001）：児童期の地域における遊び環境亡帰属意 識に関する研究：日本建築学会計画系論文集 $(550), 129$ 134

4 ）雨宮護（2012）：保護者による許可から捉えた子どもの移動 自由性と屋外遊びとの関連の地域差 : ランドスケープ研究 75(5), 477-482

5 ) 雨宮護・烟倫子・菊池城治・原田豊（2010）：保護者による 子どもに対する行動規制の要因と子どもの遊びへの影響に関 する実証的研究 - 茨城県つくば市の一小学校を事例に - : 日 本都市計画学会論文集 45(3), 79-84

6 ）曾碩文・浅川昭一郎・遠藤寛（2004）：札幌市における冬期
の戸外遊びと遊び場に関する意識の変化 : ランドスケープ研 究 67(5), 703-708

7 ）浅川昭一郎・五十嵐芳樹・鈴木波男（1994）：積雪寒冷都市 における冬期の子供の遊びについて, 日本造園学会誌 58(1), 61-64

8 ）曾碩文（2006）：子どもの戸外遊び環境としての公園整備に 関する研究, 北海道大学大学院農学研究科邦文紀要 28(1), $1-84$

9 ）谷彩音・愛甲哲也・大友雅子（2009）：積雪寒冷地における 異なる街区公園の周辺住民の利用実態と意識について: 都市 学研究 (46), 11-17

10）田川正毅・野口孝博（2007）：積雪寒冷地における子どもが 集う多世代型の地域施設の特徵：北海道・旭川市の全天候型 遊び場を事例として：日本建築学会計画系論文集 (613), 31-38

11）阿部弘明・中出文平（1993）：積雪地域における子どもの遊 び場選好に関する研究：日本都市計画学会論文集 (28), 751-756

12）公園施設（遊戯施設，便宜施設等）の設置条件は各都市公園 の選択的利用や季節間変動に影響を与えると考えられる。本 研究においても表 -5 に示した 3 タイプ間の公園施設の差異 について比較・検証を試みたものの, 公園施設の条件により タイプ間の差異を説明するまでには至らなかった。しかしな がら今後, 同様の方法による研究の継続を通してデー夕を蓄 積し, 結果を比較・検証していくことにより公園施設の差異 による児童の公園利用の季節間変動を説明することが可能に なると予測され, 今後の研究課題と考えられる。

13） $\mathrm{H}$ 校区を取り上げて事例分析を行った理由は，1．表－ 5 に示したような数值的な全体傾向に，事例による図解を加え ることによって論旨の内容理解が得られやすいこと，2．H 校区は面積規模の小さい街区公園から面積規模の大きい総合 公園まで階層性に富んだ都市公園配置を包摂していること, 3. H 校区は I 群〜 III群に含まれる公園事例をすべて含む 校区であること，4．Ｉ群〜正群の事例比較には複数校区よ りも同一校区として空間条件をそろえた方が利用の季節差を 明確に比較できるため, の 4 点である。

14） III群【冬季増加】に含まれる事例のうち農試公園では冬季利 用可能な屋内施設を有するなど，冬季利用に適した条件を有 することが冬季利用増加の要因の一つとして考えられる。

15）本研究では，個人情報保護の観点から児童の自宅所在地に関 する質問項目を調查票に加えていないためモデル化の実証ま でには至らず，あくまでも冬季の利用理由に関する記述内容 を根拠として判断した仮説的な推測にとどまる。

（2014.4.27 受付，2014.9.3 受理） 